\title{
A Tebaida como refúgio espiritual e estético em Jacopo de Varazze, Gustave Flaubert e Joris-Karl Huysmans
}

\author{
Rodrigo de Oliveira Lemos ${ }^{1}$
}

Résumé: La Thébaïde, une région désertique de l'Égypte, est associée, dans l'histoire du christianisme, à la figure de Saint Antoine et, plus généralement, à la tradition du monasticisme et de l'érémitisme comme voie ascétique vers l'expérience de Dieu. La Thébaïde est investie de cette signification dans des textes médiévaux comme la Légende Dorée, de Jacques de Voragine, où les épisodes de la vie de Saint Antoine sont dotés d'une dimension d'exemplarité. Cet espace de refuge gagne d'autres sens dans la littérature française de la deuxième moitié du XIXe siècle. Ce sont les significations de la Thébaïde caractéristiques de cette période que nous étudierons dans cet article, à partir d'une analyse de l'espace dans La Tentation de Saint Antoine (1874) de Gustave Flaubert et dans À rebours (1884) de Joris-Karl Huysmans. Nous montrerons comment, dans ces deux récits, la Thébaïde apparaît comme un espace (tantôt référentiel, tantôt métaphorique) qui évoque une version moderne de l'érémitisme où l'isolement, sans se dépouiller entièrement de l'imaginaire religieux, va de pair avec une expérience de caractère tout d'abord esthétique. Celle-ci est vécue par un sujet visionnaire qui, dégoûté de la vie en société et à l'exemple de Saint Antoine, se retire dans un espace clos où il donne libre cours aux visions intérieures suggérées par son imagination.

Mots-clés: Thébaïde; Saint Antoine; Jacopo de Verazze; Gustave Flaubert; Joris-Karl Huysmans.

Resumo: A região desértica do Egito denominada Tebaida está associada, na história do cristianismo, à figura de Santo Antônio e, de maneira mais geral, à tradição do monasticismo e do eremitismo como via ascética de vivência de Deus. É esse o sentido da Tebaida em textos medievais como a Legenda Áurea, de Jacopo de Verrazze, na qual episódios da vida de Santo Antônio ganham uma dimensão de exemplaridade. Na literatura francesa da segunda metade do século XIX, esse espaço de refúgio ganha outros sentidos. São as significações da Tebaida próprias a essa literatura que investigaremos neste artigo, a partir de uma análise do espaço em $L a$ Tentation de Saint Antoine (1874), de Gustave Flaubert, e em À rebours (1884), de Joris-Karl Huysmans. Mostraremos como, nessas duas narrativas, a Tebaida surge como um espaço (ora referencial, ora metafórico) que evoca um versão moderna do eremitismo, em que o isolamento, sem despir-se totalmente do imaginário religioso, vai de par com uma expe-

1 Doutor em Literatura pela UFRGS. Professor na Universidade Federal de Ciências da Saúde de Porto Alegre (UFCSPA), Departamento de Educação e Humanidades. Artigo vinculado ao projeto "Mito, indivíduo e sociedade: a constituição social e psicológica do sujeito moderno nas culturas de língua francesa e italiana". 
riência, em primeiro lugar, estética. Essa é vivida por um sujeito visionário que, desgostoso quanto à vida em sociedade e a exemplo de Santo Antônio, retira-se em um espaço fechado onde dá livre curso às visões interiores sugeridas por sua imaginação.

Palavras-chave: Tebaida; Santo Antônio; Jacopo de Verazze; Gustave Flaubert; Joris-Karl Huysmans.

\section{Introdução}

Ao fundo, uma pitoresca cidade se estende, plácida, com suas fortificações e seus torreões, embaçada em tons bege, de azul e de cinza pela perspectiva aérea. Há um céu de nuvens plúmbeas, varado por bichos estranhos - fusões de répteis, de peixes, de formas rizomáticas e de guerreiros carregando armaduras e maçãs. Em um plano à frente, mais nítido, ainda que sempre esmaecido, duas frescas colinas recobertas por um suave gramado se elevam. Sobre aquela à esquerda do quadro, um caminho leva a uma igreja cuja arquitetura se confunde à de um rosto em perfil, de boca escancarada, enquanto as chamas ameaçam a torre, na qual se distingue uma orelha; três criaturas de sonho, meio aves, meio humanas, sobem a senda em direção ao incêndio; mantém-se a distância um grupo de gente do povo, um homem à frente montado em um burro, as mulheres cercando um berço em que jaz, imóvel, uma criança; uma das mulheres suspende sobre o infante um caldeirão. No relevo da direita, habitado por árvores raquíticas e por pedras em forma de estranhos rostos humanos, um cavaleiro dá retaguarda sobre uma vereda a um cortejo fantástico de demônios, que desaparece para além dos limites da tela, retornando no primeiro plano para inundar a seção frontal do espaço cênico a partir da direita, povoando-a com cavalos e com cavaleiros, com anões, com seres disformes, com unicórnios e com animais compósitos. Ao mesmo tempo, um séquito de autoridades (os heresiarcas?), portando turbantes e sabres ou improváveis gorros altos, cerca uma veneranda figura barbada, à cabeça uma tiara tão peculiar quanto imponente e, nos punhos alçados no ar, uma espécie de cetro; um dos membros da comitiva, logo atrás da figura majestosa, ergue uma taça. No limite da ribalta pictórica, um ancião de longas barbas, em uma túnica frugal, lê um livro pio; duas mulheres nuas - belos demônios? - assediam-no com tamborins báquicos e com magníficos presentes dourados, enquanto, emersas do abismo à beira do qual o cortejo se equilibra, do canto inferior esquerdo do enquadramento, acorrem figuras demoníacas e tremendas - pássaros imaginários, mulheres de proporções impossíveis e de feições repulsivas - tendo às mãos acepipes e bizarros objetos musicais ricamente ornamentados, como se para tentar o solitário homem acossado por um exército de potestades da terra e do inferno, em um lugar ermo e distante para além da convivência humana delimitada pelas paredes da cidade, distante bem lá ao fundo. A cena banha-se em uma luz a pino, brilhante, que realça e aviva as cores e as formas claramente delimitadas, em uma plenitude de presença que contrasta sutilmente com seu assunto terrível e assustador, ainda que tornado quase convidativo pela fantasia extravagante e boschiana com que é urdido na tela (BRUEGHEL, s/d).

Foi dessa forma que, em A tentação de Santo Antônio, Bruegel, o Jovem (1564-1638) teria imaginado a paisagem da Tebaida, onde o santo eremita ter-se-ia retirado seguindo uma regra monástica que predicava o mais estrito isolamento, de maneira a transformar 
a solidão do deserto no teatro perfeito à batalha que se livraria a alma a si mesma e às tentações do mundo, tão mais fortes quanto mais perfeita é a reclusão. Foi também a partir dessa imagem que Gustave Flaubert concebeu um de seus principais projetos literários: a escrita de La Tentation de Saint Antoine, texto dialogado de difícil classificação, dotado de uma forma dramática, de uma dimensão lírica e de uma preocupação filosófica, composto em diversas versões, de 1848 até sua publicação em 1874.

O jovem Flaubert encontrara o quadro durante uma viagem pela Itália em 1845, exposto no Palácio Balbi, em Gênova, como ele relata em carta endereçada a Alfred Le Poittevin (a quem La Tentation é dedicada), no mesmo ano, e como viria a reafirmar em outra missiva em década mais tardia, desta vez a Mlle Leroyer de Chantepie (datada de 1872). Ao primeiro, Flaubert confia seu desejo de adquirir o quadro, caso pudesse; também manifesta seu projeto de adaptar a história do santo solitário ao teatro. À segunda, declara haver, desde sua visita a Gênova três décadas antes, retornado constantemente, em pensamento ou em leituras, ao tema daquilo que caracteriza como a obra da sua vida. Se não há mais que menções à tela na correspondência de Flaubert, é nos relatos de viagem que ele reserva um espaço maior à descrição, e consequentemente à veiculação de uma visão própria, do quadro. Após evocar alguns personagens e agrupamentos presentes na obra de Bruegel, Flaubert resume suas impressões sobre o conjunto variegado e colorido, "estranho" e "engraçado" da composição:

Ensemble fourmillant, grouillant et ricanant d'une façon grotesque et emportée, sous la bonhomie de chaque détail. Ce tableau paraît d'abord confus, puis il devient étrange pour la plupart, drôle pour quelques-uns, quelque chose de plus pour d'autres - il a effacé pour moi toute la galerie où il est. Je ne me souviens déjà plus du reste. (FLAUBERT apud JURT, 2001, p. 38)

O projeto flaubertiano de aquisição do quadro de Bruegel, facilmente adivinha-se, não prosperou, e seus meios financeiros não lhe permitiram ostentar nem uma reprodução da obra vista em Gênova. Flaubert teve de se contentar com a compra, já em 1846, de uma água-forte com esse mesmo tema datada de 1634, de autoria de Jacques Callot, pela qual ele expressa afeição em carta do mesmo ano a Louise Collet; na missiva, Flaubert concebe a gravura como expressão de uma estética que o atraía especialmente e em cujo centro estaria o que ele chama de "grotesco triste" ("grotesque triste"):

Le grotesque triste a pour moi un charme inouï ; il correspond aux besoins intimes de ma nature bouffonnement amère. Il ne me fait pas rire, mais rêver longuement. Je le saisis bien partout où il se trouve et comme je le porte en moi ainsi que tout le monde. Voilà pourquoi j'aime à analyser ; c'est une étude qui m'amuse. (ibidem)

A sensibilidade ao grotesco triste, ao "cômico que não faz rir" (como ele o definirá em outras ocasiões), goza de um lugar privilegiado na arte do romance em Flaubert: não é ele que dá o tom caricaturesco dos personagens e das situações ridículos em um romance tão impiedosamente realista como Madame Bovary (AZOULAI, 2016)?

É assim que a Tebaida representada na tela de Bruegel e na gravura de Callot inspira tanto essa modalidade particularmente amarga do humor flaubertiano, presente em seus romances mais realistas, que "não faz rir, mas devanear longamente", quanto $L a$ 
Tentation de Saint Antoine, obra das mais representativas da corrente por assim dizer histórico-orientalista da criação flaubertiana, a qual agrupa textos de sabor exotista como Salammbô ou o conto "Hérodias". Flaubert remonta a fontes antigas e medievais para reconstruir literariamente esse espaço de reclusão que é o deserto egípcio habitado por eremitas como Santo Antônio, explorando-o não somente como símbolo espiritual, mas também estético. É assim que a Tebaida estará associada, em parte da literatura francesa moderna posterior a Flaubert, a esse modo de ascese peculiarmente moderno que é o estetismo, como é o caso no romance À rebours (1884), de Joris-Karl Huysmans, que remete às paragens isoladas do Egito como metáfora do isolamento parisiense do protagonista, sob o modo da paródia e da ironia.

\section{A Tebaida e o eremitismo na tradição cristã}

A Tebaida em que se situa a história de Santo Antônio é, enquanto realidade histórica e geográfica, produto do processo de conquista e de romanização do Egito ptolomaico a partir da morte de Cleópatra, em 30 antes de Cristo. Trata-se de uma longa ocupação, que terminará apenas em 641 d.C., com a tomada de Alexandria pelos árabes (BERNAND, $\mathrm{s} / \mathrm{d}$ ). Durante esse longo período, os romanos procederam à divisão do Egito em quatro províncias: de um lado, o Egito superior e o Egito inferior; de outro, a Tebaida inferior e a Tebaida superior, as duas últimas constituídas de terras desérticas situadas na parte superior do vale do Nilo e nomeadas em referência à antiga Tebas egípcia (atualmente, Luxor), centro urbano de referência naquela região.

Com a difusão do cristianismo, e sobretudo durante os século IV e V, essas terra áridas e penosas povoam-se com monastérios. Esses se difundem sob a ação de São Pacômio (c. 292-348) a partir da comunidade de Tabenna. Trata-se de comunidades isoladas e cenobíticas (que privilegiam a vida comunitária), fortemente hierarquizadas em torno de um superior dotado de ampla autoridade sobre os monges. Sua regra monacal institui os votos de pobreza, de castidade e de obediência, além de normas quanto à vestimenta, ao trabalho manual e às mortificações (BESSE, 1912).

Além do monasticismo cenobítico, desenvolveu-se, na Tebaida, uma tendência mais extrema de reclusão, em que a ruptura do indivíduo quanto ao mundo e a seus semelhantes pretendia-se, quando não completa, mais pronunciada. Esse modo de vida religiosa, que viria a ser conhecido como eremítico (em derivação do termo grego ě $\rho \eta \mu$ s, "deserto", BESSE, 1910), teve em Santo Antônio um dos seus representantes maiores. Nascido em 251 d.C., Antônio consagra-se, a partir do seu vigésimo ano de vida, à busca da santidade em meio à solidão do deserto. A partir do seu vigésimo ano de reclusão, congrega discípulos, que imitam seu estilo de vida. Esses anacoretas ficam sob a autoridade do santo em um isolamento relativo nas grutas e cabanas que elegem como células em meio às ermas paisagens da Tebaida.

Histórias da vida de Antônio são compiladas logo após sua morte por Santo Atanásio, em 356 d.C.. Elas são como espelhos de virtude e de sabedoria que serviriam de modelo para a vida monacal. Da mesma forma, uma regra monástica de Santo Antônio - atribuída ao anacoreta, mas não de sua composição - torna-se-á referência para o monasticismo egípcio.

A importância da figura de Santo Antônio no catolicismo associa-se ao lugar destacado que ocupa o eremitismo nessa tradição religiosa. Decerto que o catolicismo nem 
sempre apregoou um desprendimento tão radical como meio de contato com o Absoluto. Também é verdade que a tendência eremítica não constitui um fenômeno exclusivo aos católicos: tanto o cristianismo oriental quanto religiões asiáticas, como o hinduísmo e o budismo, conhecem formas pronunciadas de retiro e de renúncia que não são sem lembrar o impulso que levou o "deserto a florir como o narciso" (Isaías 35) com comunidades e moradas de ermitões. Resta que o imaginário cristão acorda importância ao eremitismo, o qual está profundamente associado à ascese, a uma busca pessoal, que compreende um disciplinamento de si, na tentativa de curvar o corpo ao espírito, de impor-lhe um exercício de autodomínio a partir das exigências do Ser. É assim que se abandonam as coisas do mundo em prol de uma experiência íntima com o absoluto de Deus.

O eremitismo cristão constituiria, portanto, um meio, e não um fim; tratar-se-ia de um caminho ascético em direção a uma experiência mística. Esse caminho é definido por autores religiosos, em seu sentido profundo, e para além das imagens comuns do deserto e do isolamento, por sua liminaridade. Eremita é aquele que evitaria protagonismos e messianismos em favor de um lugar liminar, à margem. Ele o faria no ato mesmo de despojar-se: em busca da essencialidade e da frugalidade, o eremita renunciaria a posses e a seguranças; sua pobreza atingiria o desnudamento; optaria pela despossessão para preservar-se da ambição e do egoísmo, para descobrir-se em sua identidade pessoal e para, nada tendo, conservar-se no espírito de partilha. Por isso igualmente cultivaria o silêncio - não, decerto, o silêncio que traduziria uma incomunicabilidade, nem é verdade que ele se recusaria a dialogar; é que é pela quietude do eremita que ele se faria amigo da palavra, nele rara e pausada, por radicar na meditação e na escuta da voz interior. A sua se proporia a ser uma via de purificação, uma ascese pela qual o homem religioso combateria os impulsos negativos em si mesmo e ao seu redor, na procura por uma pacificação que não seria indiferença, nem acomodação, mas que manifestaria uma ausência de conflitualidade. Essa seria conquistada em um caminho ascendente que compreenderia o autocontrole, a compaixão e, finalmente, a disponibilidade para as obras de paz. Por fim, o eremita seria habitado pela consciência de que os valores, inclusive aqueles que germinam no eremitismo, seriam dons do Espírito e só se enraizariam mediante a sua disponibilidade ativa como discípulo (DE CANDIDO, 2003, p. 360-363).

\section{Santo Antônio na Idade Média: a Legenda Áurea}

A existência do monasticismo egípcio seguirá vigorosa mesmo no momento em que a Tebaida passa ao domínio bizantino, vindo a conhecer um declínio com a tomada do Egito pelos sarracenos, no século VII. A queda de Alexandria não impediu, entretanto, que a memória de Santo Antônio permanecesse influente durante a Idade Média, primeiro em virtude dos relatos de Santo Atanásio, depois pela inclusão de sua biografia na Legenda Áurea. Texto imensamente difundido nos últimos dois séculos da Idade Média, composto em latim em meados do século XIII (a data exata da composição está sujeita à discussão crítica) pelo arcebispo de Gênova e frade dominicano Jacopo de Varrazze (1228-1298), a Legenda Áurea é uma compilação hagiográfica (o termo legenda se refere em latim àquilo "que deve ser lido") tida como dotada de elevado valor moral e pedagógico (ela é "áurea"). Essa coletânea de vidas de santos serve como repositório dos exempla a serem evocados por clérigos e pregadores junto a seus ouvintes, constituindo, assim, parte fundamental daquilo que Hilário Franco Júnior chamou de "cultura intermediária” medieval, 
agrupando referências partilhadas entre as diversas camadas da sociedade do Medievo, dos eruditos aos populares. Não surpreende, desse modo, que um dos 175 capítulos redigidos por Jacopo de Verrazze seja dedicado a Santo Antônio, santo exemplar entre todos por sua virtude, sua sabedoria e sua coragem espiritual. Haja vista a divulgação massiva da obra tanto em latim quanto nas línguas vernáculas (dentre as quais o italiano, o francês, o alemão, o catalão, o espanhol e o boêmio), em um período tão longo que vai desde a sua publicação até a Renascença, tampouco é de surpreender que a imagem do eremita Santo Antônio deva muitos de seus traços fundamentais à hagiografia composta com fins didáticos pelo arcebispo de Gênova (FRANCO JÚNIOR, 2003, p. 11-25).

O incipit da hagiografia de Santo Antônio na Legenda Áurea compreende, como é o caso em outros capítulos, uma explicação etimológica do nome do santo, menos científica (no sentido moderno estrito) do que religiosa, mesclando radicais gregos e latinos. A significação do seu nome (ana, advérbio grego significando "embaixo", e tenens, particípio presente do verbo tenere, que referiria "aquele que abraça as coisas do alto e despreza as da terra", como descreve Jacopo de Verrazze) conteria e ecoaria a significação ascética da própria figura de Santo Antônio: aquele que "desprezou o mundo que é imundo, inquieto, transitório, enganador, amargo" (VERRAZZE, 2011, p. 171). Trata-se de uma sensibilidade pessimista quanto às coisas terrestres, a qual Verrazze estreia na autoridade de Santo Agostinho. Da mesma forma, o autor remete explicitamente os fatos reportados no corpo do texto à autoridade de Atanásio.

O relato tem início com a resolução de Antônio, aos 20 anos, de retirar-se do mundo, tendo ouvido numa prédica o chamado do Cristo ao despojamento total em favor dos pobres. $\mathrm{O}$ apelo ascético é prontamente obedecido, mas ele logo encontra a resistência dos demônios. Os combates entre esses e o santo compõem a primeira parte da narrativa sobre a sua vida eremítica e se repetem oito vezes: primeiramente, o diabo aparece como um menino negro que seduz os jovens para a fornicação; por duas vezes seguidas, o santo é assediado junto a um túmulo em que se penitenciava por uma multidão de demônios sob forma de feras vorazes; também o diabo deixa traços tentadores, como um prato de prata e uma maçã de ouro, encontrados no meio do deserto; são igualmente os demônios que, durante uma visão, interrompem a suspensão de Antônio no ar pelos anjos, e, por duas vezes, Satanás se lhe revela como gigante, na primeira ocasião tentando-o, na segunda, inquirindo-o. Em todas essas passagens, o santo triunfa sobre as potestades do mal, com o concurso seja dos anjos, seja do Cristo; em todas, dá provas da sua própria capacidade de resistência. São esses oito momentos exempla, episódios modelares que ilustram a fortaleza do eremita no embate com as forças que investem contra seu propósito salvífico (uma passagem em que Antônio busca o martírio quando das perseguições do Imperador Maximiano só vem reforçar essa ideia, ainda que o mal nesse caso se incarne nos hereges e não nos demônios, como é o caso nos outros trechos).

Se essas narrativas são paragonos de coragem, os episódios seguintes o são de sabedoria. Há no texto sete circunstâncias que reportam palavras de caráter sapiencial saídas da boca do santo. A primeira é a parábola do arqueiro: nela, o eremita ensina a necessidade do descanso, mesmo àqueles que se dedicam às obras do senhor; na seguinte, Antônio discorre, em uma conversa, sobre os três pontos a se observar para agradar a Deus (ter Deus diante dos olhos; agir de acordo com as Escrituras; não deter-se sobre nenhuma passagem delas com pressa excessiva). Em seguida, um diálogo com um abade ilustra o imperativo de isolamento para os monges que escolhem viver em retiro, bem como seu dever de lutar 
contra seu único inimigo: seu próprio coração; na sequência, uma conversação com outros monges mostra o santo advertindo-os contra a loquacidade e a facilidade de palavra. A série dos exempla sapienciais se fecha por uma passagem em que Antônio reprime um outro anacoreta por não se haver totalmente despojado de seus bens.

O conjunto seguinte de eventos dessa hagiografia demonstra o caráter visionário do santo. São três as visões relatadas. Antônio vê no deserto um anjo do Senhor que lhe ensina a trabalhar e a rezar, como forma de burlar o tédio. Antônio vê a ascensão das almas e o diabo retendo algumas delas - salvo as dos santos -, ao som de cânticos de alegria e de urros de dor. Antônio vê no céu cavalos destruindo a coices o trono do Senhor; o narrador interpreta a aparição como anúncio do arianismo ${ }^{2}$. Seguem-se a esse grupo de acontecimentos as narrações finais, de caráter heteróclito: primeiro, a morte de um nobre egípcio, seguidor de Ário, uma vez tendo escarnecido das recomendações ao arrependimento por parte de Antônio; em seguida, o chamado à prece que o santo oferece a um grupo de monges refratários ao árduo preceito evangélico de dar a outra face ao inimigos. O relato se conclui pela evocação da morte do eremita, aos 105 anos, em um passamento tranquilo, que soa como uma recompensa às atribulações e às asperezas conhecidas por Antônio em seu impiedoso combate interior.

\section{Visões de Santo Antônio na Tebaida de Flaubert}

Essas atribulações e essas asperezas estão, por sua vez, no cerne de La Tentation de Saint Antoine, de Flaubert. Desde a entrada do texto, cuja ação se estende do crepúsculo ao amanhecer, Santo Antônio é o eremita na Tebaida; sua vida familiar, seus discípulos (dentre os quais o favorito, Hilarion), as circunstâncias de sua conversão, suas errâncias pelo Egito, tudo isso já é pretérito quando o monólogo do anacoreta começa, deixando-se evocar em suas palavras inaugurais tão-somente como lembrança; a noite vem encontrá-lo sozinho na Tebaida, pronto ao combate interior, in media res, acossado por tentações demoníacas.

Os sete capítulos de La Tentation de Saint Antoine consistem, assim, numa apresentação, no modelo do debate ou do desfile, dessas tentações, algumas referentes à vida instintual e dos sentidos, outras de caráter intelectual e doutrinário. As primeiras investidas do Diabo ainda são cruas, evidentes: Antônio questiona-se em seu sacrifício eremítico, inveja a vida dos laicos; nas suas leituras pias, ele as entremeia a comentários em que é visitado pela gula, pela cólera, pela inveja; ao longo do seu discurso, é de novo o orgulho e a inveja, mais a gula e a luxúria, sob sedutoras vozes femininas, que o assediam, testando seu limite, até sua perda de consciência (capítulo I). Ao resistir, Antônio só faz atiçar ainda mais o Diabo, que acorre, ladeado pelos Sete Pecados Capitais, e logo alucinações tomam o santo, pondo-o à prova na gula (pela visão de um banquete imaginário), na avareza (no episódio da bandeja e da massa de ouro, oriunda da Legenda Áurea), na ira (vingando-se dos arianos), no orgulho e na inveja (contra os Pais católicos presentes no Concílio de Nicéia), finalmente na luxúria (ao ser tentado pela Rainha de Sabá), episódios escandidos por quedas e penitências por parte do eremita (capítulo II). Diante das recusas,

2 Doutrina ligada ao bispo Ário e dada por herética em 325, no Concílio de Niceia; no século IV, o arianismo disputava a hegemonia à ortodoxia católica ao pregar a subordinação do Filho ao Pai na Santa Trindade, reduzindo o Cristo a primeira e mais excelente das criaturas (BELLINGER, 2000, p. 171). 
as forças demoníacas redobram a aposta, assumindo a forma de Hilarion; a artimanha do Diabo se aguça ao tomar o melhor e mais amado discípulo de Santo Antônio como aquele que precisamente veicula as mais finas e mais irrefutáveis objeções à fé ortodoxa, atacando ora inconsistências nos relatos neotestamentários, ora a exclusividade dos estudos sacros frente aos humanísticos, ora a base racional da fé, evocando aporias ante a diversidade irredutível das doutrinas heréticas e a veracidade dos martírios que cada uma delas inspira, por contraditórias que sejam (capítulo III).

A questão doutrinal introduzida pelo personagem de Hilarion abre o cortejo de heresiarcas e de infiéis que tentam Santo Antônio com controvérsias filosóficas e teológicas dos mais variados matizes, reproduzindo os debates dos quatro primeiros séculos da cristandade, de alguns dos quais o próprio Santo Antônio tomou parte. É assim que, ao longo do extenso capítulo IV, assaltam-no as facções e os doutrinários gnósticos (Manes, Orígenes, Saturnino, Cerdão, Marcião, Bardesanes, Valentino, Basílides, os hernianos, os priscilianos); destacam-se aqueles que praticavam formas orgíacas de religação com a divindade ou que exaltavam o que a ortodoxia entende como crimes, vícios e opiniões extravagantes (Aécio, os caropocracianos, os nicolaitas, os marcosianos, os helvidianos, os messalianos, os paternianos). Também integram o desfile dos heréticos os adeptos do montanismo (Montano, Tertuliano, Priscila, Maximila), seguidos pelos rigoristas adeptos de práticas extremas contra a obra criada, como a castração, as mortificações radicais, as diversas formas de desordem social ou a recusa aos sacramentos (o próprio Montano, os arcônticos, os tatianianos, os valesianos, os cainitas, os circonceliões, entre outros). Esses são seguidos por representantes das diferentes correntes de opinião heréticas sobre a natureza divina ou humana de Jesus, debate premente à época de Antônio: primeiramente, o próprio Ário, depois Sabélio, os valentinianos, os setianianos, os teodocianos, os merintianos, os apolinaristas, além das figuras de Marcelo de Ancira, do papa Calisto, de Metódio, de Cerinto, de Paulo de Samosata, de Hermógenes, passando ainda pelos judeus e os ebionitas. O cenário muda, e seguem-se a turba dos mártires e um gimnosofista, tentando-o com o exemplo do auto-sacrifício pio não diferente do dele próprio, apenas baseado na religião hinduísta. Finalmente, encerram a parada o gnóstico Simão, o Mágico, e o neopitagórico Apolônio, ambos mestres na manipulação do sagrado, seja pela magia, seja por milagres espetaculares.

Se os heresiarcas não conseguem curvar o santo a golpes de retórica e de dialética, as divindades, ainda mais poderosas, tentarão fazê-lo ao desfilarem em seu esplendor, uma vez convocadas por Hilarion (capítulo V). O séquito de deuses começa no Oriente, com a profusão dos deuses indianos e de ascetas (tão mais perturbadores a Antônio que eles não são menos ferrenhos do que ele próprio nos exercícios ascéticos, ainda que se consagrem a outras divindades). Shiva, Vishnu, Brahma, todos se curvam diante das palavras do Buda, figura apresentada em analogia à do Cristo, em sua caridade, em seu amor universal e em suas práticas ascéticas; seu discurso contra os brâmanes é posto em paralelo por Hilarion às reprimendas do Cristo aos fariseus, e o ex-discípulo se serve dessa semelhança para abalar a crença do santo: "Tu viens de voir la croyance de plusieurs centaines de millions d'hommes!" (FLAUBERT, 1983, p. 170).

O arco geográfico dos deuses desloca-se a oeste: vêm os deuses persas (Oanes, Ormuz), os da Babilônia (e as práticas de prostituição sagrada), os cultos ctônicos gregos (Diana de Éfeso, Cibele), os cultos egípcios, finalmente o Olimpo em seu esplendor e em sua decadência. Outros cultos menores seguem, como os deuses da Samotrácia, da 
Etrúria, as divindades rústicas romanas (Sartor, Sarrator, Vallona), os Lares dos latinos, enfim a voz possante e, ao fim, mais e mais longínqua de Jeová, o deus dos Exércitos, o Senhor. É chegado a essa extremidade que Hilarion se revela em sua face verdadeira; ele cresce ao seu ponto mais extremo, perde-se da vista do santo; Hilarion se revela como a Ciência, cujo "royaume est de la dimension de l'univers", cujo "désir n'a pas de bornes", sempre "sans haine, sans pitié, sans amour et sans Dieu" (ibidem, p. 206). Antônio adivinha: esse deus desconhecido de outras eras - e tão próprio a essa segunda metade do século XIX, positivista e naturalista, na França em que viveu Flaubert - não pode ser outro senão o Diabo. Assim descoberto, e tendo recobrado sua verdadeira forma, este último rapta o anacoreta em um voo que não é sem lembrar ao leitor atento o de Mefistófoles com Fausto (e que faz a substância do capítulo VI). O Diabo sem a roupagem de Hilarion excele na inteligência argumentativa que caracteriza o discípulo, e o voo é a ocasião para tentar o anacoreta com a visão das imensidões estelares (referência a Pascal?) e com perguntas, essenciais, sobre o sentido teleológico do universo, que o Diabo nega, a fim de convencer Antônio a cultuá-lo. Aos primeiros raios da aurora, o anacoreta deve se haver com dois pares de tentadores: uma mulher jovem e uma velha, a primeira a luxúria (que o convida ao olvido nos excessos na carne), a segunda a morte (cujo chamado ao suicídio é também um chamado à libertação); depois a Quimera e a Esfinge, símbolos da fantasia e do pensamento, que introduzem um séquito de monstros míticos (o Grifo, o Basílico, o Unicórnio) e de animais marinhos, estes últimos levando a visão de Antônio a seres mais e mais primitivos, até a própria eclosão da vida. É então que raia o dia, e, no disco solar, o santo tem a visão beatífica do rosto do Cristo; limita-se ao sinal da cruz e à prece, gesto que, em seu laconismo (capítulo VII), conclui o texto flaubertiano, deixando mais ambiguidades do que certezas.

O encadeamento de visões em que consiste La Tentation de Saint Antoine instaura uma relação com o espaço sob o modo da clivagem entre o espaço físico e o espaço experienciado. O primeiro identifica-se inteiramente com a Tebaida. Essa situação na geografia real é anunciada logo na entrada do texto, na frase inaugural: " $C$ 'est dans la Thébaïde, au haut d'une montagne, sur une plate-forme arrondie en demi-lune, et qu'enferment de grosses pierres" (FLAUBERT, 1983, p. 51). O espaço fala da piedade do seu ocupante: há uma cabana ao fundo, feita de "boue et de roseaux, à toit plat, sans porte" (ibidem), habitada por não mais que um jarro, um pão preto, um púlpito com um livro, espartarias, esteiras, uma cesta, uma faca, e, fora da morada humilde do eremita, uma cruz assinala o caráter religioso do seu retiro.

A geografia da Tebaida é pintada de maneira a sugerir um quadro de isolamento, e a paisagem faz as vezes de cela monacal para o contemplativo. O espaço em que se desenvolve a provação espiritual de Antônio é, como vimos, encerrado por grandes penedos; não somente isso, "la montagne est taillée à pic, et le Nil semble faire un lac au bas de la falaise" (ibidem). Apesar de a cena desenrolar-se ao ar livre, a impressão geral é de sufocamento, de prisão ("La vue est bornée à droite et à gauche par l'enceinte des roches", ibidem). Se a visão interior do santo é pródiga, as vistas das imensidões desérticas da Tebaida, que se oferecem, monótonas, ao seu olho físico, apresentam bem menos variações: "comme des plages qui se succéderaient, d'immenses ondulations parallèles d'un blond cendré s'étirent les unes derrière les autres, en montant toujours". Mesmo o panorama da grandeza desmesurada da Tebaida é contido por limites físicos; para além da planície, a cadeia de montanhas da Líbia "forme un mur couleur de craie" (ibidem), como as paredes de um claustro. 
É pelas visões que se revelam espaços muito distantes e distintos da Tebaida. Em uma das suas primeiras visões, Antônio "se croit en Alexandrie" (idem, p. 70), no tempo das controvérsias com os arianos; a metrópole egípcia, evocada com erudição em seus detalhes urbanísticos, é o cenário imaginário em que o asceta dá vazão aos seus pendores violentos no combate aos heréticos; é também ali que é atiçado na vaidade, ao se fazer confidente de Constantino e ao gozar com a humilhação dos medalhões do Concílio de Niceia. A visão logo subsequente o transporta à Babilônia bíblica, especificamente à corte de Nabucodonosor, antes de ele acordar do devaneio e dar com o despojamento e a solidão silenciosa do deserto ("L'enceinte des roches est vide. Les étoiles rayonnent. Tout se tait.", idem, p. 76).

Outras imagens arrebatam Antônio - a visita da Rainha de Sabá, do demônio da fornicação sob a forma de um menino negro (já presente, aliás, na Legenda), de Hilarion - sem a supressão do espaço físico. Ainda assim, o espaço ilusório retorna no capítulo IV, com as discussões com os heresiarcas, que têm lugar em uma "basilique immense" (idem, p. 97), repleta de povos distintos, de seitas conflitantes, uma balbúrdia em que Antônio e Hilarion imergem até um trono em que pontifica o profeta Manes. Ali, debatem com os demais heresiarcas; depois de uma breve volta de sua consciência à cabana, o eremita perde-se novamente na alucinação do circo em que trava contato dos mártires cristãos abandonados às bestas feras, em provável referência às perseguições do imperador Maximiano; depois, na de uma floresta em que se martiriza pelo fogo o gimnosofista.

A própria Tebaida pode não ser apagada pelas visões, mas metamorfoseada por elas, como ocorre no episódio do gimnosofista, em que a planície se transforma em floresta ("la plaine s'est transformée", idem, p. 129); o mesmo se dá quando o cenário se prepara à aparição dos deuses indianos: ("La vallée devient une mer de lait, immobile et sans bornes. Au milieu flotte un long berceau, composé par les enroulements d'un serpent dont toutes les têtes, s'inclinant à la fois, ombragent un dieu endormi sur son corps.", idem, p. 163), ou quando as rochas que circundam Antônio se transformam no Monte Olimpo. Outras mudanças espaciais céleres, porque ditadas pela fantasia, levam Antônio e Hilarion ao topo de um zigurate para assistir ao desfile dos deuses caldeus e a seus ritos; no capítulo VI, projetam-no ao puro espaço sideral nas asas de Satã ou, ainda, no capítulo final, ao meio da Tebaida, onde confronta-se à sequência de monstros míticos. O eclodir da vida, por sua vez, tem lugar em um espaço por assim dizer a-espacial, ou pré-espacial, já que é também quando Antônio flagra o nascer do próprio movimento, o momento de abalo do ser ao vir-a-ser (“J'ai vu naître la vie, j'ai vu le mouvement commencer.", idem, p. 237), antes de sua consciência retornar à Tebaida para contemplar o rosto de Cristo no sol a pino.

O narrador passeia com um mesmo olhar por esses dois planos espaciais, o real da Tebaida e o imaginário, das alucinações. Há uma intenção descritiva minuciosa no tratamento de ambos esses espaços, como se a pluma de Flaubert quisesse esgotá-los na apreensão de seus detalhes e traduzi-los em uma visão plástica. Se é precípua a característica visionária do protagonista, a presença intensa do visto no ato de ver do santo, o narrador flaubertiano oferece-se como seu duplo, tentando comunicar essa verdade da visão imaginária por uma escrita esquadrinhante do objeto inexistente como se ele de fato e realmente existisse.

\section{O eremitismo decadentista em À rebours, de Joris-Karl Huysmans}

"Aérolithe dans le champ de foire littéraire" (HUYSMANS, 1997, p. 36), como o definiu Joris-Karl Huysmans em um prefácio redigido em 1903, À rebours vem a público 
em 1884, em um cenário literário fortemente marcado pelo realismo e pelo naturalismo. A influência de Flaubert deixa-se adivinhar em filigrana na narrativa de Huysmans, desde o prefácio, em que o autor situa a estética do romance em contrapé a narrativas naturalistas ou realistas como L'Assomoir ou como L'Éducation Sentimentale, esta última referencial para o círculo de Zola, dada por Huysmans como obra tão acabada de um certa estética do romance que constituía aos escritores subsequentes uma via sem saída. Daí que a obra flaubertiana não seja recusada tout court pelo autor de À rebours. Ao contrário, Des Esseintes, o herói desta narrativa de isolamento e de aventura interior não menores que La Tentation de Saint Antoine, consagra as melhores palavras à "admirable prose" do autor (idem, p. 149), citando em especial as ficções históricas em que se ressaltava a "Antiquité si merveilleusement ressuscitée par Flaubert" (idem, p. 234). Dentre essas, cita Salammbô e a própria Tentation, cujo episódio da Esfinge e da Quimera inspira uma das aventuras sexuais de Des Esseintes e que ele preferia a L'Éducation Sentimentale; nessas obras, "loin de notre vie mesquine, il évoquait les éclats asiatiques des vieux âges, leurs éjaculations et leurs abattements mystiques, leurs démences oisives, leurs férocités commandées par ce lourd ennui qui découle, avant même qu'on les ait épuisées, de l'opulence et de la prière" (idem, p. 225-226).

Bem entendido, a importância de Flaubert, e em especial de La Tentation de Saint Antoine, no texto de Huysmans ultrapassa essas referências e citações explícitas, mas pontuais. Sua influência é mais pervasiva e se faz sentir fundamentalmente tanto na concepção do personagem quanto na constituição do espaço em que ele evolui. A exemplo da obra de Flaubert, À rebours também consiste em uma narrativa de renúncia e de retiro. Trata-se de uma espécie de ascese transcorrendo na Paris fin-de-siècle, onde o último rebento de uma família aristocrática plurissecular, Jean Floressas des Esseintes, desgostoso com a vida numa sociedade republicana em processo de laicização e corroída por aspirações venais, decide isolar-se em um paraíso artificial nos arredores da capital, em uma solidão estrita, avessa ao mínimo contato humano, dando-se a prazeres estéticos e intelectuais cuja extremidade algo sobre-humana no refinamento tem algo de paródico. Os 16 capítulos da narrativa acompanham a instalação, o processo e o término dessa reclusão, fases que também correspondem à progressão da neurose na vida psíquica do personagem, de mais em mais isolado. Seu refúgio é concebido com termos oriundos do monasticismo. Seus gostos na literatura latina pendem aos fins da Antiguidade, aos tempos vividos por Santo Antônio, sobretudo aos "écrivains décadents, latins et monastiques des vieux âges " (idem, p. 208), o mesmo dando-se quanto à música oriunda dos ambientes monásticos ("il n'approuvait réellement que la musique monastique du Moyen Âge", idem, p. 251). Mais geralmente, ele distingue um paralelo entre si mesmo e os enclausurados: ele era 'tel qu'un ermite", "tel qu'un moine", pronto ao isolamento por cansaço e por desespero quanto à vida; ainda que desprovido de fé, movia-o "une réelle sympathie pour ces gens enfermés dans des monastères, persécutés par une haineuse société qui ne leur pardonne ni le juste mépris qu'ils ont pour elle ni la volonté qu'ils affirment de racheter, d'expier, par un long silence, le dévergondage toujours croissant de ses conversations saugrenues ou niaises" (idem, p. 108). Mesmo o espaço em que Des Esseintes se encerra é influenciado pela vida monacal, e ele cogita moldar seu quarto como uma "cellule monastique", retendo-o apenas a repulsa pela "austère laideur des asiles à pénitence et à prière" (idem, p. 106).

É na concepção geral do espaço que a memória da Tebaida se faz mais sensível na narrativa de Huysmans. Des Esseintes elege morada em um cenário que não poderia ser 
mais distante do deserto povoado de anacoretas; seu retiro é em Fontenay-aux-Roses, nos subúrbios de Paris; encontra aí um recanto que o preservava a distância dos seus conterrâneos, ao mesmo tempo que o mantinha próximo o suficiente da metrópole para reconfortar-se em sua solidão. E, ainda assim, é bem o deserto de Santo Antônio que o narrador evoca, como metáfora, para descrever esse quadro prosaico ao extremo: "Déjà il rêvait à une thébaïde raffinée, à un désert confortable, à une arche immobile et tiède où il se réfugierait loin de l'incessant déluge de la sottise humaine" (idem, p. 45). Tebaida refinada, de fato, pois o desvelo do protagonista para transformar essa casa de subúrbio em um espaço que traduza o Ideal ocupa uma parte importante do texto, em realidade seus cinco primeiros capítulos, em que flagramos as pesquisas de Des Esseintes na escolha dos móveis e das cores (capítulo I), da sala de jantar (capítulo II), do seu gabinete de trabalho e da biblioteca (capítulo III), do "orgue à bouche" (capítulo IV) e dos quadros que ornam suas salas (capítulo V).

Não somente o seu lugar de exílio se compara à Tebaida, mas uma divisão semelhante à que marca o refúgio do santo em Flaubert reina no reduto suburbano de Des Esseintes. A narrativa de Huysmans compreende igualmente aquele contraste que nos é familiar em La Tentation de Saint Antoine: de um lado, o espaço real (de Paris, de Fontenay-aux-Roses); do outro, as visões de espaços fantasmados que desfilam na imaginação do recluso e que estão no âmago do relato. Um tal descompasso é explorado em diversos episódios de À rebours, mas fica especialmente evidente quando Des Esseintes estabelece o plano de viajar a Londres para escapar ao tédio que o esmaga em Fontenay. A aventura ocupa o essencial do capítulo XI, acompanhando o protagonista em sua deliberação de partir para a Inglaterra, inspirado por suas leituras de Dickens, assim como suas paradas no caminho da estação, por um fim de tarde chuvoso, em lugares altos da anglofilia na Paris fin-de-siècle, como no gabinete de leitura Galignani's Messenger (onde Des Esseintes deseja comprar um guia de Londres), o Bodéga (bar repleto de ingleses, onde Des Esseintes saboreia uma taça de Porto enquanto fantasia os personagens de Dickens e de Poe) e a taverna da rue d'Amsterdam, onde janta e onde a sua viagem imaginária chega ao término. Em cada uma das paradas desse percurso cujo clima enevoado e pluvial lembra-lhe o de Londres, Des Esseintes experimenta visões da Inglaterra que ele deseja visitar, seja no ambiente dotado de uma "tournure mercantile", incomum ao refinamento parisiense, do Galignani's Messenger, onde um guia sobre os museus londrinos o faz devanear sobre as telas dos pré-rafaelitas; seja no Bodéga, em que a visão dos ingleses reais ali presentes mistura-se à dos personagens dickensianos; seja ainda na taverna, em que a cozinha e a frequentação inglesa do ambiente o transportam por alguns instantes a Londres.

Não somente a divisão entre espaço real e espaço imaginado permitem-no viajar para além da Mancha sem sair do lugar, como também transforma o deslocamento físico em fonte de decepção. É do que se lembra Des Esseintes durante o jantar na taverna e que o decide a permanecer em Paris. Ele havia, em uma viagem à Holanda durante o seu período mundano, partido em busca da terra imaginada pelos mestres da pintura de gênero exposta no Louvre; uma vez chegado ao país real, deu-se conta de que fora enganado por aquelas "visions inégalables" dos Ostade e dos Rembrandt: a Holanda nada mais tinha de "primitif", de "bonhomme"; onde estavam as "joies effrénées, as "ivrogneries familiales" representadas nas telas (idem, p. 180)? O país havia cedido ao ethos protestante, "avec ses rigides hypocrisies et ses solennelles raideurs" (idem, p. 180-181), e é a memória desse desapontamento que o conduz, como um Du Bellay solitário e melancólico, de 
volta à sua casa, alquebrado pelo "éreintement physique et la fatigue morale d'un homme qui rejoint son chez soi, après un long et périlleux voyage” (idem, p. 182). Essa viagem do personagem a Londres sem sair de Paris está longe de ser a única no seu gênero, e, entre outras, o narrador se consagra igualmente a descrever como, sem deixar seu retiro de Fontenay-aux-Roses, Des Esseintes dedica-se, por intermédio de sais, de corantes, de fotos, de objetos e de leituras temáticas, a criar "l'illusion de la mer" - o mar, esse là-bas indefectível - nas águas de sua banheira (idem, p. 60-61).

\section{Conclusão: o visionário como santo e como eremita}

Nada aparenta maior distância do que a Tebaida desértica do século IV de Santo Antônio, tal qual evocada por Jacopo de Verrazze, e a "tebaida refinada" onde se isola o eremita na Paris decadentista evocado por Huysmans. E, no entanto, a ligação entre ambos os imaginários existe e se faz perceptível na história literária francesa. Essa ponte se encontra na obra de Flaubert.

La Tentation de Saint Antoine diverge da narrativa presente na Legenda Áurea pelo fato de que a tentativa de Flaubert é menos a de relatar os milagres e os episódios, de caráter exemplar, da vida do santo do que evocar em minúcia as visões que o tomam. Assim, a obra reforça o caráter interior das experiências do eremita, segundo a tradição da mística cristã, às expensas de qualquer exemplaridade; ao mesmo tempo, transforma seu significado, menos espiritual do que estético: é como se o interesse de Flaubert fosse menos as manifestações do divino ou do diabólico do que a veiculação, por meio de uma linguagem minuciosa e exaustiva, e em uma visão plástica, das alucinações que assombram Antônio.

Com efeito, é o trabalho da imaginação estética que atrai Flaubert à tela de Brueghel e é também a imaginação que ele coroa no texto da Tentation. Significativamente, é essa mesma rainha das faculdades que o baudelairiano herói de Huysmans, igualmente visionário, estimula e suscita em suas experiências estéticas. Daí a centralidade do espaço, e em especial o descompasso entre os espaços real e imaginário, nas obras de Flaubert e de Huysmans. Nessas duas narrativas de isolamento (entre os penedos da Tebaida ou entre as paredes de uma casa burguesa, que importa?) e de ascese - em suma, de busca de submissão do material ao ideal, do corpo ao espírito, da natureza ao simbólico -, é sempre o espaço interior que é visado por esses dois eremitas que são o santo e o esteta, ambos visionários alimentados de leitura e de cultura da Antiguidade tardia os quais, a exemplo de Mallarmé, leram todos os livros e testemunham dos debates abstrusos das autoridades e das seitas do primeiro cristianismo (HUYSMANS, 1997, p. 121-123).

A relação com o espaço real não é, decerto, precisamente a mesma em Flaubert e em Huysmans. Se o isolamento de Santo Antônio se faz ressaltar por seu extremo despojamento, as descrições dos esforços e da minúcia na luxuosa decoração por Des Esseintes do seu refúgio em Fontenay-aux-Roses colocam o espaço físico na narrativa de Huysmans sob o signo do excesso e da saturação. É que a visão é suscitada sobrenaturalmente no santo da Tebaida e às expensas do espaço real do deserto, que ou desaparece, ou é transformado em outra coisa quando as alucinações sobrevêm. Já a "tebaida refinada" em Fontenay-aux-Roses é o próprio elemento suscitador da visão imaginária no herói de Huysmans, e seu afã no manejo do espaço físico da sua morada traduz a consciência desse modo de relação entre real e imaginário, bem como a vontade de gerir o espaço físico 
em vista do espaço imaginado. Daí que estas duas narrativas, em que o cerne da ação é reduzido ao seu mínimo, consistem, em realidade, no encadeamento e na progressão das visões de seus protagonistas.

O término dessas paradas de visões, mais e mais extremas e sofridas, coincide com o término das narrativas. Sua interrupção se dá com a evocação do divino. Essa intervenção, no entanto, abre mais ambiguidades do que as resolve. No caso do Santo Antônio de Flaubert, a face do Cristo no disco solar interrompe o desfile de tentações ante a seu olho interior, mas deixa subentendida a questão: o que distingue essa aparição do Bem quanto às anteriores, inspiradas pelo demônio, quanto à sua realidade? Uma ambiguidade quanto à transcendência formulada, por sua vez, explicitamente por Des Esseintes, ao chamar esse mesmo Cristo em que não pode crer e que, ao mesmo tempo, representa a evasão absoluta: "Seigneur, prenez pitié du chrétien qui doute, de l'incrédule qui voudrait croire, du forçat de la vie qui s'embarque seul, dans la nuit, sous un firmament que n'éclairent plus les consolants fanaux du vieil espoir !" (idem, p. 269). Pode a representação do eremita concebida em uma sociedade em processo de "saída da religião"3 não evocar essa possível e angustiosa Ausência?

\section{Referências}

AZOULAI, Juliette. « Ridiculus sum : le ridicule dans Madame Bovary ». In: Flaubert [En ligne], 16, 2016, mis en ligne le 08 décembre 2016. Disponível em: http://journals. openedition.org/flaubert/2658. Acesso em 09 de julho de 2019.

BELLINGER, Gerhard J. Encyclopédie des religions.e Préface de Pierre Chaunu, de l'Institut. Paris: Le Livre de Poche, coll. "Encyclopédies d'aujourd'hui", 2000. Traduit de l'allemand sous la direction de François Livi.

BERNAND, André. ÉGYPTE ANTIQUE (Histoire) - L'Égypte romaine et byzantine. In: Encyclopcedia Universalis [en ligne] Disponível em : http://www.universalis.fr/ encyclopedie/egypte-antique-histoire-l-egypte-romaine-et-byzantine/. Acesso em 3 de setembro de 2019.

BESSE, J. (1910). Hermits. In: The Catholic Encyclopedia. New York: Robert Appleton Company. Disponível em: http://www.newadvent.org/cathen/07280a.htm. Acesso em 2 de setembro de 2019.

. (1912). Thebaid. In: The Catholic Encyclopedia. New York: Robert Appleton Company. Disponível em: http://www.newadvent.org/cathen/14561a.htm. Acesso em 2 de setembro de 2019.

BRUEGHEL, O JOVEM, Peter. A tentação de Santo Antônio. s/d. Disponível em: https://flaubert.univ-rouen.fr/derives/tsa_brueghel.php. Acesso em 3 de setembro de 2019. DE CANDIDO, L. Eremitismo. In: BORRICELLO, L. et al. Dicionário de mística.. São Paulo: Paulus, 2003, p. 360-363. Tradução de Benôni Lemos et al FLAUBERT, Gustave. La Tentation de Saint Antoine. Paris: Gallimard, coll. "Folio", 1983.

3 Remetemos ao conceito de "sortie de la religion", de Marcel Gauchet, sem, no entanto, podermos nos deter sobre o mesmo devido às limitações de espaço neste trabalho, mas remetemos à seguinte síntese do pensamento do autor: GAUCHET Marcel. Pourquoi L'Avènement de la démocratie?. In: Le Débat, Paris: Gallimard, n. 183, p. 182-192, janvier-février 2017. 
FRANCO JÚNIOR, Hilário. Apresentação. In: VERRAZZE, Jacopo de. Legenda Áurea. São Paulo: Companhia das Letras, 2011, p. 11-25. Traduzida do latim por Hilário Franco Júnior.

GAUCHET, Marcel. Pourquoi L'Avènement de la démocratie?. In: Le Débat, Paris: Gallimard, n. 183, p. 182-192, janvier-février 2017.

HUYSMANS, Joris-Karl. À rebours. Paris: Pocket, 1997.

URT, Joseph. Flaubert e as artes visuais. In: Alea - estudos neolatinos, Rio de Janeiro, Volume 4, no 1, p. 33-54, janeiro-junho de 2001. Disponível em: http:/www.letras. ufrj.br/pgneolatinas/media/alea/volume $\% 204 \% 20$ numero $\% 201 / 4.1 \% 20 b \% 29 \% 20$ JURT,\%20Joseph.\%20Flaubert\%20e\%20as\%20artes\%20visuais.pdf. Acesso em 9 de julho de 2019.

VERAZZE, Jacopo de. Legenda Áurea. São Paulo: Companhia das Letras, 2011. Traduzida do latim por Hilário Franco Júnior.

Recebido em: 10/09/2019; Aceito em: 23/10/2019 